\title{
PENGARUH EKSTRAK AKAR ENCOK TERHADAP PERTUMBUHAN STAPHYLOCOCCUS AUREUS
}

\author{
Anak Agung Inten Pradnya Suamami ${ }^{1}$, I Gede Sudarmanto ${ }^{2}$., Nyoman Mastra ${ }^{3}$.
}

\begin{abstract}
Background Resistance is defined as growth inhibition of bacteria with antibiotics. Staphylococcus aureus bacteria is known to be resistant to gentamicin and methicillin. Staphylococcus aureus can cause various infection of the skin, injuries, and system.

Methods This research is true-experimental with Posttest-Only Control Group Design and using Kirby-Bauer method by means of five concentration (20, 40, 60, 80, dan 100\%). The negative control uses sterile distilled water, and the positive control uses Vancomycin $30 \mu \mathrm{g}$. Result This research showed the mean of inhibition zone diameter of each concentration consecutively $16 \mathrm{~mm}, 20 \mathrm{~mm}, 22 \mathrm{~mm}, 23 \mathrm{~mm}$, and $23 \mathrm{~mm}$. Oneway ANOVA statistic analysis showed that the value of $p$ is 0,000 that mean there is an influence of encok roots extract to Staphylococcus aureus growth.

Conclusion There is an influence of encok roots extract to Staphylococcus aureus growth. Seen from its ability to inhibit the growth of Staphylococcus aureus.
\end{abstract}

Keywords: Plumbago zeylanica L.; roots extract; Staphylococcus aureus

\section{PENDAHULUAN}

Plumbago zeylanica L. merupakan obat herbal serba guna pada famili Plumbaginaceae. Plumbago zeylanica adalah tanaman paling umum yang digunakan pada cara pengobatan tradisional India. Tanaman ini berasal dari Asia Selatan, dan terdistribusi di sebagian besar daerah tropis serta subtropis. Plumbago zeylanica tumbuh di hutan gugur, sabana, dan semak belukar yang akarnya dari permukaan laut hingga 2000 meter diatas permukaan laut. Akar Plumbago zeylanica digunakan sebagai obat pencahar (ekspektoran), astringent, abotifatient dan disentri. Larutan alkohol dari kulit akar digunakan sebagai antiperiodik. Daunnya sengit dan digunakan pada perawatan scabies ${ }^{1}$.

Dalam pengobatan Ayurweda dan Sidda, Plumbago zeylanica telah digunakan untuk formulasi obat-obatan Ayurweda. Tumbuhan ini digunakan untuk demam, diare, masalah pencernaan, pilek, masalah kulit seperti kusta/lepra dan malaria di India.

1.,2.3., Jurusan Analis Kesehatan Poltekkes Denpasar Korespondensi : Anak Agung Inten Pradnya Suamami ${ }^{1}$, Jurusan Analis Kesehatan, Poltekes Denpasar, Jalan Sanitasi No. 1 Sidakarya, DenpasarBali 80224, Indonesia.

Telp. +62-361-710 527, Fax. +62-361-710 448

Email : meditoryjournal@gmail.com 
Tumbuhan ini digunakan sebagai antivirus di Nepal, di Taiwan dapat digunakan sebagai aktivitas anti-heliobakteri. Plumbago zeylanica juga digunakan untuk antioksidan di Madras. Selain itu tumbuhan ini digunakan untuk masalah lambung dan penyakit parasit, serta scabies di Ethiopia dan Nigeria ${ }^{2}$.

Resistensi didefinisikan sebagai tidak terhambatnya pertumbuhan bakteri dengan pemberian anti biotik secara sistemik dengan dosis normal yang seharusnya atau kadar hambat minimalnya ${ }^{3}$. Pemakaian antibiotik yang tidak teratur, tidak tepat atau tidak sesuai resep dapat meningkatkan resistensi bakteri terhadap antibiotik. Resistensi bakteri terhadap antibiotik merupakan salah satu masalah kesehatan yang dihadapi belakangan ini.

Berdasarkan hasil penelitian Gambaran Pola Resistensi Bakteri di Unit pola kuman yang paling banyak dijumpai di unit perawatan neonatus RSHAM adalah Staphylococcus sp, Pseudomonas sp dan Enterobacter sp yang sensitif terhadap vancomycin, meropenem dan amikacine sedangkan penggunaan antibiotik lini pertama yaitu ampicillin, gentamicin dan cefotaxime telah resisten.

Staphylococcus aureus termasuk dalam keluarga Micrococcaceae dan merupakan bagian dari genus
Staphylococcus, yang berisi lebih dari 30 spesies seperti $S$. epidermidis, $S$. saprophyticus dan S. haemolyticus. Di antara spesies staphylococcal, Staphylococcus aureus adalah yang paling ganas dan patogen untuk manusia. Staphylococcus aureus adalah bakteri Grampositif. Di laboratorium dapat diamati sebagai sel tunggal, berpasangan atau sebagai kelompok teratur seperti anggur ${ }^{4}$.

Staphylococcus aureus dapat menyebabkan berbagai infeksi dari berbagai kulit, luka dan infeksi jaringan dalam kondisi yang mengancam jiwa lebih seperti pneumonia, endokarditis, arthritis septik dan septikemia. Bakteri ini juga merupakan salah satu spesies yang paling umum pada infeksi nosokomial. Staphylococcus aureus juga dapat menyebabkan keracunan makanan, sindrom scalded-kulit dan toxic shock syndrome, melalui produksi racun yang berbeda ${ }^{4}$.

Seiring dengan berkembangnya ilmu pengetahuan dan teknologi, disamping pemberian antibiotik sebagai obat antibakteri, stigma masyarakat tidak lepas dari penggunaan obat-obat herbal atau obat tradisional. Penggunaan obat tradisional dipilih karena faktor turun-temurun atau kepercayaan, dan memiliki efek samping yang lebih kecil dibandingkan dengan obatobatan medis. 
Indonesia sebagai negara tropis memiliki kekayaan flora meliputi tanaman yang dapat difungsikan sebagai obat. Salah satunya adalah tanaman Encok (Plumbago zeylanica L.). Tanaman ini memiliki nama berbeda pada beberapa wilayah di Indonesia seperti, Ceraka (Sumatera), Daun encok, Ki encok (Sunda), Gadong encik, Poksor (Jawa), Kareka (Madura), Bama (Bali) dan Oporie (Timor) ${ }^{5}$.

Berdasarkan

Phytochemical

Screening and Antimicrobial Studies on Plumbago zeylanica L. oleh Subash ${ }^{5}$, zat-zat aktif dari akar Encok seperti saponin, karbohidrat, steroid, alkaloid, flavonoid, dan tanin dapat diekstraksi dengan pelarut yang berbeda dan disimpulkan bahwa ekstrak metanol da $\mathrm{n}$ etanol akar Plumbago zeylanica L. dapat menghambat pertumbuhan Staphylococcus aureus masing-masing sepanjang $16 \mathrm{~mm}$ dan 10 mm. Untuk memaksimalkan pemanfaatan dari tanaman ini, peneliti ingin mengetahui pengaruh Ekstrak Akar Encok (Plumbago zeylinica L.) terhadap Staphylococcus aureus dengan pelarut akuades dengan berbagai macam konsentrasi.

\section{METODE}

Jenis penelitian yang digunakan adalah penelitian true-experimental. Pengujian aktivitas antibakteri dilakukan dengan metode difusi dengan cara KirbyBauer dilakukan di laboratorium
Mikrobiologi Fakultas Kedokteran Universitas Udayana.

Tahap penelitian dilakukan dengan penanaman bakteri Staphylococcus aureus pada media Mueller Hinton Agar. Kemudian masing-masing cakram disk yang mengandung ekstrak akar encok konsentrasi 20, 40, 60, 80 dan 100\% diukur. Kontrol negatif (cakram disk mengandung akuades steril) dan kontrol positif (cakram disk mengandung vankomisin $30 \mu \mathrm{g}$ ) juga ditempelkan pada permukaan media. Media MHA yang telah ditempeli cakram disk diinkubasi pada inkubator selama 24 jam dengan suhu $37^{\circ} \mathrm{C}$. Hasil zona hambat pertumbuhan Staphylococcus aureus yang terbentuk pada masing-masing cakram disk dinyatakan dalam satuan milimeter (mm).

\section{HASIL DAN PEMBAHASAN}

\section{Hasil}

Data yang diperoleh selanjutnya di analisis menggunakan uji statistik Kolmogorov Smirnov. Pada uji tersebut diperoleh hasil nilai $p=0,323$, jika dibandingkan dengan nilai $\alpha(0,05)$ maka nilai $p$ lebih besar dari $\alpha(0,323>0,05)$. Berdasarkan uji tersebut, diketahui bahwa data penelitian ini berdistribusi normal.

Setelah diperoleh hasil data berdistribusi normal, uji statistik dilanjukan dengan Oneway Annova Test untuk menguji apakah ada pengaruh ekstrak akar encok terhadap 
Tabel 1. Data Hasil Penelitian Pengaruh Ekstrak Akar Encok terhadap Pertumbuhan Staphylococcus aureus

\begin{tabular}{|c|c|c|c|c|c|c|c|c|}
\hline \multirow{3}{*}{ No } & \multirow{3}{*}{ Konsentrasi } & \multicolumn{6}{|c|}{ Zona Hambat (mm) } & \multirow{3}{*}{ Rata- rata } \\
\hline & & \multicolumn{3}{|c|}{ Replikasi 1} & \multicolumn{3}{|c|}{ Replikasi 2} & \\
\hline & & 1 & 2 & 3 & 1 & 2 & 3 & \\
\hline 1 & $20 \%$ & 14 & 16 & 17 & 15 & 18 & 15 & 16 \\
\hline 2 & $40 \%$ & 21 & 20 & 20 & 19 & 20 & 18 & 20 \\
\hline 3 & $60 \%$ & 23 & 21 & 21 & 20 & 22 & 20 & 21 \\
\hline 4 & $80 \%$ & 26 & 21 & 23 & 23 & 23 & 21 & 23 \\
\hline 5 & $100 \%$ & 24 & 22 & 23 & 21 & 24 & 22 & 23 \\
\hline 6 & Kontrol (-) & 0 & 0 & 0 & 0 & 0 & 0 & 0 \\
\hline 7 & Kontrol (+) & 18 & 18 & 18 & 18 & 17 & 19 & 18 \\
\hline
\end{tabular}

pertumbuhan Staphylococcus aureus. Pada uji Oneway Annova diperoleh nilai probabilitas $p=0,000$ dengan tingkat kepercayaan $95 \%(0,05)$.

Untuk menganalisis perbedaan zona hambat ekstrak akar encok terhadap pertumbuhan Staphylococcus aureus dapat diketahui dengan melakukan uji LSD (Least Significant Different). Uji LSD menunjukan terdapat perbedaan bermakna konsentrasi $20 \%$ terhadap konsentrasi 40, 60, 80, dan $100 \%$ yang ditunjukan dengan nilai $\alpha(0,05)$ lebih besar dibandingkan nilai $p(0,000)$. Adanya perbedaan bermakna juga terdapat pada konsentrasi $40 \%$ terhadap konsentrasi $80 \%$ dan $100 \%$ dengan nilai $p=0,001$ dan konsentrasi $60 \%$ terhadap konsentrasi $80 \%$ dengan nilai $p=0,046$, dimana nilai probabilitas tersebut masih lebih kecil dibandingkan nilai $\alpha(0,05)$. Namun, pada uji ini menunjukan tidak ada perbedaan signifikan antara konsentrasi $40 \%$ terhadap $60 \%$ dan konsentrasi $60 \%$ terhadap $100 \%$ dengan nilai $p=0,070$, dan konsentrasi $80 \%$ terhadap konsentrasi $100 \%$ dengan nilai $p=$ $0,835(p>\alpha(0,05))$.

\section{Pembahasan}

a. Panjang diameter zona hambat pada kontrol

Tujuan penggunaan kontrol dalam penelitian ini yaitu sebagai pembanding hasil diameter zona hambat perlakuan. Kontrol yang digunakan dalam penelitian ada dua yaitu, kontrol negatif dengan akuades steril dan kontrol positif dengan vankomisin $30 \mu \mathrm{g}$. Akuades steril tidak memiliki zat antimikroba harus bernilai negatif atau menghasilkan panjang diameter zona hambat dengan nilai $0 \mathrm{~mm}$. Sedangkan kontrol positif digunakan sebagai 
pembanding terhadap hasil zona hambat perlakuan untuk menetapkan tingkat resisten, intermediet, atau sensitif.

Pada penelitian ini kontrol negatif tidak menimbulkan zona hambat untuk pertumbuhan bakteri Staphylococcus aureus karena akuades steril tidak memiliki zat antimikroba. Rata-rata diameter kontrol negatif sepanjang $0 \mathrm{~mm}$ sedangkan kontrol positif memiliki rata-rata diameter sepanjang $18 \mathrm{~mm}$.

Pemilihan antibiotik lain yang sekarang digunakan untuk mengobati Staphylococcus aureus yang telah resisten terhadap turunan penisilin yaitu vankomisin dan teikoplanin ${ }^{6}$.

Selain itu vankomisin termasuk dalam golongan antibiotik yang mekanisme kerjanya menghambat sintesis atau merusak dinding sel bakteri. Vankomisin diindikasikan untuk infeksi yang disebabkan oleh Staphylococcus aureus yang resisten terhadap meticilin (MRSA) ${ }^{7}$. Setelah dibandingkan dengan tabel, diameter zona hambat cakram vankomisin $30 \mu \mathrm{g}$ lebih dari $15 \mathrm{~mm}$ (>15 mm) termasuk dalam kelompok sensitif dalam menguji Staphylococcus. Hasil kontrol positif dari penelitian ini termasuk dalam kelompok sensitif yaitu 18 $\mathrm{mm}$

b. Panjang diameter zona hambat terhadap perlakuan
1) Diameter zona hambat pada konsentrasi $20 \%$

Berdasarkan pengukuran diameter zona hambat ekstrak akar encok konsentrasi $20 \%$ didapatkan hasil dengan rata-rata 16 mm. Dengan konsentrasi 20\% ekstrak akar encok dapat menghambat pertumbuhan Staphylococcus aureus sepanjang $16 \mathrm{~mm}$.

2) Diameter zona hambat pada konsentrasi $40 \%$

Konsentrasi 40\% ekstrak akar encok menghasilkan rata-rata diameter zona hambat sebesar $20 \mathrm{~mm}$ dan jika dibandingkan dengan kontrol positif (vankomisin $30 \mu \mathrm{g}$ ) pada tabel NCCLS termasuk dalam sifat sensitif. Berdasarkan pengukuran, rerata diameter zona hambat pada konsentrasi 40\% lebih besar dari konsentrasi 20\% (20 mm >16 mm). Ekstrak akar encok konsentrasi $40 \%$ dapat menghambat pertumbuhan bakteri Staphylococcus aureus sepanjang $20 \mathrm{~mm}$,

3) Diameter zona hambat pada konsentrasi $60 \%$

Ekstrak akar encok konsentrasi $60 \%$ menghasilkan diameter zona bening dengan rata-rata $21 \mathrm{~mm}$. Hasil ini tidak berbeda jauh dari rata-rata diameter konsentrasi $40 \%$ dan jika dibandingkan dengan kontrol positif (vankomisin $30 \mu \mathrm{g}$ ) pada tabel NCCLS termasuk dalam sifat sensitif. 
4) Diameter zona hambat pada konsentrasi $80 \%$

Berdasarkan pengukuran diameter zona hambat ekstrak akar encok dengan konsentrasi $80 \%$ didapatkan rata-rata 23 mm. Jika dibandingkan dengan kontrol positif (vankomisin $30 \mu \mathrm{g}$ ) pada tabel NCCLS, ekstrak akar encok konsentrasi $80 \%$ termasuk dalam sifat sensitif.

5) Diameter zona hambat pada konsentrasi $100 \%$

Pengukuran terakhir pada konsentrasi $100 \%$, didapatkan rata-rata diameter sebesar $23 \mathrm{~mm}$. Ekstrak akar encok konsentrasi $100 \%$ termasuk dalam sifat sensitif dan hasil reratanya tidak berbeda dari konsentrasi $80 \%$.

Hasil penelitian menunjukan semakin tinggi konsentrasi ekstrak akar encok, maka semakin besar diameter zona hambatnya. Hal tersebut dikarenakan semakin tinggi konsentrasinya, kandungan zat aktif sebagai penghambat bakteri juga semakin banyak. Namun, terdapat hasil yang sama yaitu pada konsentrasi $80 \%$ dan $100 \%$.

Kesamaan hasil zona hambat pada konsentrasi $80 \%$ dan $100 \%$ mungkin disebakan karena ekstrak konsentrasi 100\% lebih pekat, sehingga zat-zat aktifnya tidak dapat berdifusi dengan maksimal. Ekstrak akar encok konsentrasi $100 \%$ dapat menghampat pertumbuhan bakteri Staphylococcus aureus sepanjang $23 \mathrm{~mm}$.

Zona bening atau zona hambat yang terbentuk dari perlakuan ekstrak akar encok 20, 40, 60, 80, dan 100\% terhadap bakteri Staphylococcus aureus dikarenakan zat-zat aktif antibakteri yang terdapat dalam ekstrak sehingga dapat menghambat pertumbuhan bakteri tersebut. Ekstrak akar encok (Plumbago zeylanica L.) dengan berbagai macam pelarut ditemukan zat-zat antioksidan seperti saponin, steroid, alkaloid, flavonoid, dan tanin.

Saponin bekerja sebagai antibakteri dengan mengganggu stabilitas membran sel bakteri sehingga menyebabkan sel bakterilisis. Mekanisme kerja saponin termasuk dalam kelompok antibakteri yang mengganggu permeabilitas membran sel bakteri, yang mengakibatkan kerusakan membran sel dan menyebabkan keluarnya berbagai komponen penting dari dalam sel bakteri yaitu protein, asam nukleat dan nukleotida.

Alkaloid sebagai antibakteri memiliki mekanisme sebagai inhibitor pertumbuhan bakteri adalah dengan cara mengganggu komponen penyusun peptidoglikan pada sel bakteri, sehingga lapisan dinding sel tidak terbentuk secara utuh dan menyebabkan kematian sel tersebut. 
Flavonoid adalah golongan terbesar dari senyawa fenol. Senyawa fenol memiliki kemampuan antibakteri dengan cara mendenaturasi protein yang menyebabkan terjadinya kerusakan permeabilitas dinding sel bakteri.

$$
\text { Kandungan Tanin dapat }
$$
mengganggu permeabilitas membran sel bakteri dan memiliki kemampuan mencegah koagulasi plasma pada Staphylococcus aureus $^{8}$.

Berdasarkan pemaparan diatas ditunjukan bahwa adanya pengaruh ekstrak akar encok terhadap pertumbuhan Staphylococcus aureus. Sehingga penelitian mengenai ekstrak akar encok ini sangat bermanfaat bagi masyarakat dan diharapkan dapat dimanfaatkan untuk mengatasasi infeksi yang disebabkan oleh Staphylococcus aureus.

\section{SIMPULAN DAN SARAN}

Terdapat pengaruh ekstrak akar encok terhadap pertumbuhan Staphylococcus aureus. Rerata zona hambat ekstrak akar encok pada konsentrasi 20\% sebesar $16 \mathrm{~mm}$, pada konsentrasi $40 \%$ sebesar $20 \mathrm{~mm}$, konsentrasi $60 \%$ sebesar 21 mm, dan konsentrasi $80 \%$ dan $100 \%$ sebesar $23 \mathrm{~mm}$.

Konsentrasi 20\% ekstrak akar encok merupakan konsentrasi yang efektif untuk menghambat pertumbuhan Staphylococcus aureus. Terdapat perbedaan bermakna konsentrasi $20 \%$ terhadap konsentrasi 40, 60,80 , dan $100 \%$ dengan nilai $\alpha(0,05)$ lebih besar dibandingkan nilai $p(0,000)$.

Saran untuk masyarakat agar dapat memanfaatkan ekstrak akar encok sebagai salah satu upaya pencegahan infeksi yang disebabkan oleh Staphylococcus aureus.

Bagi calon peneliti disarankan penelitian ini mencari KHM (Koefisien Hambat Minimum) ekstrak akar encok untuk mengetahui konsentrasi minimum yang efektif untuk membunuh bakteri Staphylococcus aureus.

Menggunakan bahan uji yang lebih mudah dibuat dan diaplikasikan kepada masyarakat seperti perasan, dan penelitian ini dapat menjadi bahan referensi untuk penelitian selanjutnya.

\section{DAFTAR PUSTAKA}

1. Jain, Paras, et al., Pharmacological Profiles of Ethno-Medicinal Plant: Plumbago zeylanica l.-A Review, Ranchi: Laboratory of Plant Phyciology and Biotechnology, Univercity Departement of Botany. 2013.

2. Anonim, t.t, Plumbago zeylanica (plumbaginaceae)Online:http://www.m mhmms.com/downloads/mp15plumbag ozeylanica.pdf, Diakses tanggal 25 Januari 2015.

3. Rahayu, Eka, Antibiotika, Resistensi, dan Rasionalitas Terapi Online: 
http://ejournal.uin-

malang.ac.id/index.php/sainstis/article/v iewFile/-1861/pdf_1. Diakses tanggal 25 Januari 2016. 2012.

4. Stark, Lisa, Staphylococcus aureus Online : $\quad$ http://liu.divaportal.org/smash/get/diva2:647005/FUL LTEXT01.pdf. (Diakses tanggal 25 Januari 2016). 2013,

5. Datta, Sanjana dan RN, Mishra, , Plumbago zeylinica Linn. (Chitrak)Review as Rasayan (Rejuvenator/ Antiaging). India: Sanggar Institute of Pharmaceutial Sciences. 2012

6. Sulistianingsih, Uji Kepekaaan Beberapa Sediaan Antiseptik terhadap Bakteri Staphylococcus aureus dan Staphylococcus aureus Resisten Metisilin (MRSA) Online : http://pustaka.unpad.ac.id/wpcontent/uploads/2010/11/uji_kepekaan_ beberapa_sediaan_antiseptik_tdhp_bakt eri_resisten_metisilin.pdf, Diakses 19 Juni 2016. 2010.

7. Depkes, Permenkes RI No. 2406/MENKES/PER/XII/2011 tentang Pedoman Umum Penggunaan Antibiotik Online: http://www. binfar.depkes.go.id/dat Permenkes Antibiotik.pdf, Diakses tanggal 19 Juni 2016. 2011.

8. Tammi, Alfan, , Perbandingan Daya Hambat Ekstra Daun Salam (Syzygium polyanthum [Wight.] Walp.) terhadap Pertumbuhan Bakteri Staphylococcus aureus dan Escherichia coli secara In Vitro

Online:http://digilib.unila.ac.id/21636/3 /SKRIPSI\%20TANPA\%20BAB\%20PE MBAHASAN.pdf, (Diakses tangga 21 Juni 2016). 2016. 
